\title{
Growth, Productivity and Quality of Okra (Abelmoschus esculentus L.) cv. Prabhani Kranti and Nutrient Balance in Soil under Chemical Fertilizers, Organic Manures and Biofertilizers in Sub-Tropical Condition
}

\author{
Ps. Mariam Anal ${ }^{1}$, Edwin Luikham ${ }^{1}$, Ps. Munsi $^{2}$ and W.I. Meitei ${ }^{1}$ \\ ${ }^{1}$ Central Agricultural University, Imphal-795 004, India \\ ${ }^{2}$ Palli Siksha Bavana, Visva Bharati, Sriniketan-731 236, West Bengal, India \\ *Corresponding author
}

\begin{abstract}
A B S T R A C T
An experiment was conducted to find out suitable integrated nutrient management in okra cv. Prabhani Kranti with the aim to maximise growth, yield and quality under sub-tropical condition. The experiment was laid out in randomized block design replicated thrice with

\begin{tabular}{|c|}
\hline Keywords \\
\hline $\begin{array}{l}\text { Okra, Chemical } \\
\text { fertilizers, Organic } \\
\text { manures, Biofertilizers, } \\
\text { Yield, Quality and soil } \\
\text { nutrients }\end{array}$ \\
\hline Article Info \\
\hline $\begin{array}{l}\text { Accepted: } \\
\text { 12 September } 2018 \\
\text { Available Online: } \\
10 \text { October } 2018\end{array}$ \\
\hline
\end{tabular}
15 treatments. The result revealed that application of $75 \%$ recommended dose of NPK along with FYM or vermicompost at $5 \mathrm{t} / \mathrm{ha}$ significantly enhanced the growth of the crop at different stages as expressed in terms of leaf area index, fresh and dry weight of the plant and NAR. The combination of $75 \%$ recommended NPK dose with either vermicompost or FYM at $5 \mathrm{t} / \mathrm{ha}+$ with or without Azospirillum remarkably enhanced the green fruit yield/ha. Higher nitrogen, phosphorus and potassium content of leaves at flowering time were associated with combined application of $75 \%$ recommended NPK dose + vermicompost or FYM at $5 \mathrm{t} / \mathrm{ha}+$ with or without Azospirillum. Integration of higher levels of major nutrients with FYM/ vermicompost along with Azospirillum increase the crude protein content but decrease the crude fibre content of green fruit of okra. The combined application of 75\% recommended dose of NPK + vermicompost at 5 t/ha with or without Azospirillum recorded higher postharvest available soil NPK as compared to rest of the other treatment. Higher positive nitrogen and potassium balance was associated with the integration of organic and inorganic nutrient application, however, the balance of phosphorus was found to be negative irrespective of the treatments.
\end{abstract}

\section{Introduction}

Okra (Abelmoschus esculentus L.) belongs to Malvaceae family, originating from tropical and sub-tropical Africa (Tindal, 1983). It is an important vegetable crop grown for its green tender fruits during the summer season in Manipur. Fresh tender okra fruits are used as vegetable while the roots and stems are used for preparing 'gur' or brown sugar (Chauhan,
1972). The seeds in the fresh edible pods of okra provide vitamins, minerals, calories and amino acid and compares favourably with those in poultry, eggs and soybean (Thompson, 1949; Schipper, 2000). The mucilage of the pod has medicinal properties as an emollient, laxative and expectorant (Muresan and Popescu, 1993). The edible portion of the pod contains approximately water 88 , protein 2.1 , fat 0.2 , carbohydrate 
8.0, fibre 1.7 and ash $0.2 \mathrm{~g}$ per $100 \mathrm{~g}$ (Tindal, 1983).

Being a short duration vegetable crop, okra requires proper and sufficient nutrition to provide regular fruiting with quality yield. Lack of sufficient amounts of nutrients will result in poor performance of the crop growth and ultimately lower the yield (Shukla and Naik, 1993).

Use of chemical fertilizer has undoubtedly enhanced the production of vegetable crops but it is now causing serious concern on decline in productivity due to deteriorating effect on soil physical and chemical environment and high energy requirement. Contrary to chemical fertilizers, use of organic manure or compost will help to improve soil health and in turn enhance the yield per unit of nutrient applied and thereby save energy. Sustainable and eco-friendly agriculture which minimizes the use of harmful energy intensive inputs is achievable through the use of organics and biofertilizers. Organic nutrition for vegetables is important as it provides quality food, which is very important for providing health security to the people. Since the vegetables are mostly consumed as fresh or partially cooked, they should be devoid of harmful residual effect of chemical fertilizers. Increase in the yield of chilli, okra, tomato and brinjal by the application of organic manures was reported by Gaur et al., (1984). The produce obtained from organic farming is nutritionally superior with good taste, luster and better keeping qualities as indicated in many scientific studies earlier. Now a days, the practice of using biofertilizers has a partial substitute for chemical fertilizers is gaining much momentum. Azospirillum is an associative symbiotic nitrogen fixing bacterium having high potential for nitrogen fixation and produces growth hormones. Thus, integrated nutrient management involving chemical fertilizers along with organic manure, Vermicompost and Azospirillum is quite imperative for maintenance of long term soil health and productivity in okra. Integrated nutrient sources increase the nutrient use efficiency and soil fertility and thus, enhanced the productivity as well as the quality of the produce (Singh, 1996).Keeping this in view, the present investigation was carried out to evaluate the most suitable combination of chemical fertilizers, organic manures and biofertilizer for okra.

\section{Materials and Methods}

The present investigation was carried out at the Horticultural Experimental Farm, College of Agriculture, Central Agricultural University, Imphal during the summer season of 2008 and 2009. The soil of the experimental field was clayey in texture having $\mathrm{pH}$ 5.4; organic carbon $1.20 \%$; available nitrogen 320 , phosphorus 25.08 and potassium $450 \mathrm{~kg} / \mathrm{ha}$. The experiment was laid out in a randomized block design with fifteen treatments and replicated thrice. The treatments are $\mathrm{T}_{1}=100 \%$ recommended NPK dose $\quad(80: 60: 30 \mathrm{~kg} / \mathrm{ha}), \quad \mathrm{T}_{2}=75 \%$ recommended NPK dose, $\mathrm{T}_{3}=50 \%$ recommended NPK dose, $\mathrm{T}_{4}=75 \%$ recommended NPK dose + FYM at 5 t/ha, T $_{5}$ $=50 \%$ recommended NPK dose + FYM at 5 $\mathrm{t} / \mathrm{ha}, \mathrm{T}_{6}=75 \%$ recommended NPK dose + FYM at 5 t/ha+ Azospirillum, $\mathrm{T}_{7}=50 \%$ recommended NPK dose + FYM at 5 t/ha+ Azospirillum, $\mathrm{T}_{8}=75 \%$ recommended NPK dose + Vermicompost at $5 \mathrm{t} / \mathrm{ha}, \mathrm{T}_{9}=50 \%$ recommended NPK dose + Vermicompost at 5 t $/$ ha, $\mathrm{T}_{10}=75 \%$ recommended NPK dose + Vermicompost at $5 \mathrm{t} / \mathrm{ha}+$ Azospirillum, $\mathrm{T}_{11}=$ $50 \%$ recommended NPK dose + Vermicompost at $5 \mathrm{t} / \mathrm{ha}+$ Azospirillum, $\mathrm{T}_{12}=$ FYM at $5 \mathrm{t} / \mathrm{ha}, \mathrm{T}_{13}=$ Vermicompost at $5 \mathrm{t} / \mathrm{ha}$, $\mathrm{T}_{14}=$ Azospirillum and $\mathrm{T}_{15}=$ Control .

The required half dose of nitrogen, full dose of phosphorus and potassium in the form of urea 
$(46 \% \mathrm{~N})$, single super phosphate $\left(16 \% \mathrm{P}_{2} \mathrm{O}_{5}\right)$ and muriate of potash $\left(60 \% \quad \mathrm{~K}_{2} \mathrm{O}\right)$ were applied uniformly to each plot one day before sowing and mixed properly with the soil. The remaining half dose of nitrogen was top dressed at 30 days after sowing. Charcoal based inocula Azospirillum brasilense was applied at $20 \mathrm{~g} / \mathrm{kg}$ seeds as per the treatments in the experiment. The FYM $(0.6,0.18,0.40 \%$ NPK) and Vermicompost (1.36, 0.58, $0.71 \%$ $\mathrm{NPK})$ at $5 \mathrm{t} / \mathrm{ha}$ each were applied to respective plots as per treatments. The seed of okra cv. Prabhani Kranti at the rate of $20 \mathrm{~kg} / \mathrm{ha}$ was sown in $3 \mathrm{~cm}$ depth maintaining a spacing of $40 \times 20 \mathrm{~cm}$. Cultural practices like weeding, hoeing, irrigation, etc were common for all the treatments. The mean NAR was calculated by the formula given by Enyi (1962) and expressed in $\mathrm{mg} \mathrm{m}^{-2}$ day $^{-1}$.

$\mathrm{NAR}=\left[\mathrm{W}_{2}-\mathrm{W}_{1} / \mathrm{t}_{2}-\mathrm{t}_{1}\right] \times\left[\log _{\mathrm{e}} \mathrm{L}_{2}-\log _{\mathrm{e}} \mathrm{L}_{1} /\right.$ $\left.\mathrm{L}_{2}-\mathrm{L}_{1}\right]$

Where,

$\mathrm{W}_{1}=$ Plant dry weight in $\mathrm{t}_{1}$ days

$\mathrm{W}_{2}=$ Plant dry weight in $\mathrm{t}_{2}$ days

$\mathrm{L}_{1}=$ Total leaf area per plant in $\mathrm{t}_{1}$ days

$\mathrm{L}_{2}=$ Total leaf area per plant in $\mathrm{t}_{2}$ days

The biochemical analysis was done using standard method. The estimation of nitrogen in green fruits was done by the Kjeldhal method (Jackson, 1973). From the nitrogen percentage, crude protein content was estimated by employing the standard factor of 6.25 and expressed in per cent. The crude fibre content in the fresh palatable fruits of okra was analyzed as per the method described by Chopra and Kanwar (1976). In calculating the balance sheet of nutrients, the uptake by crops and available NPK in soil were taken into account. Nutrient balance was calculated using the formula as described by Yadav (1981).

Nutrient balance in soil $=\mathrm{Y}-(\mathrm{x}-\mathrm{a})-\mathrm{N}$
Where,

$\mathrm{Y}=$ nutrient removed by crop

$\mathrm{x}=$ initial nutrient status of the soil

$\mathrm{a}=$ final nutrient status of the soil

$\mathrm{N}=$ nutrient added through fertilizer/manure

\section{Results and Discussion}

\section{Growth}

Increased in the growth characters like leaf area index (LAI), fresh and dry weight of plant and Net Assimilation Rate (NAR) at different stages of okra were recorded with integration of $75 \%$ recommended NPK dose along with either Vermicompost or FYM at 5 t/ha and with or without Azospirillum (Table 1 and 2). These treatments were comparable to $100 \%$ recommended NPK dose but superior to either 75 or $50 \%$ NPK dose alone or FYM or Vermicompost or Azospirillum individually with few exceptions. This increase in growth characters may be attributed to greater availability of nutrients from both fertilizer and organic manures. The integration of Vermicompost or FYM would have facilitated better aeration, adequate drainage and created a favourable soil environment for deeper penetration of roots and higher nutrient extraction. The better efficiency of organic manures in combination with inorganic fertilizers might be due to the fact that the organic manures would have provided the micro-nutrients such as zinc, iron, copper, manganese, etc. in an optimum level. Zinc is involved in the biochemical synthesis of the most important phyto-hormone, Indole Acetic Acid (IAA) through the pathway of conversation of tryptophan to IAA. Iron is involved in the chlorophyll synthesis biochemical pathway. Copper and manganese are the important co-enzymes for certain respiratory reactions. Similar beneficial effect of integrating NPK + FYM or poultry manure in LAI of brinjal confirms the earlier report of 
Naidu et al., (2002). Akanbi et al., (2010), ElKader et al., (2010) and Sachan et al., (2017) also reported significant increase in fresh and dry weight of okra plant with organic and inorganic fertilization. The positive effect of combining fertilizers with organic manures and biofertilizers in okra was also reported by Mishra et al., (2005) and Akande et al., (2010).

\section{NPK content of leaf at flowering time}

Combined application of $75 \%$ recommended NPK dose with Vermicompost/FYM + with or without Azospirillum resulted in higher nutrient content of leaf at $50 \%$ flowering of the crop and it was comparable to $100 \%$ recommended dose of NPK (Table 3). However, the influence of these treatments on potassium content of leaf was remarkable only in second year of experimentation which may be attributed to higher initial available potassium in soil and thus the response was less. Increase in leaf NPK content due to application of fertilizers alone or in combination with organic sources and biofertilizer in okra was reported by Singh et al., (2004). The poor content of nutrient in leaf with either FYM or Vermicompost or Azospirillum alone and lower NPK dose might be due to inadequate availability of nutrients as demanded by the crop.

\section{Yield}

In the present study the strategy of applying either $100 \%$ recommended dose of NPK or $75 \%$ recommended dose of NPK combined with Vermicompost/FYM at 5 t/ha with or without Azospirillum appears to match the crop demand and different physiological stages and reduces the losses of nutrients as reflected in recording the highest green fruit yield (Table 3). Thus, the increased availability of nutrients at distinct physiological phases would have supported for better assimilation of photosynthates towards fruits. Increase in green fruit yield can also be attributed to favourable effect of accelerating the growth and yield components. Besides the beneficial effect of fertilizers, the added organic manures improved the soil physical, chemical and biological properties which are a well-known fact, thus, it helped in better nutrient absorption by plants resulting in higher fruit yield. Bahadur and Manohar (2001), Phonglosa et al., (2015) and Sachan et al., (2017) in okra also established such beneficial effect of integrating organic and inorganic fertilizers + Azospirillum. Though numerically higher fruit yield was observed in either Vermicompost or FYM or Azospirillum alone, it was comparable to control. The reason for obtaining similar yield in these treatments may be due to inadequate availability of nutrients when it was applied singly as expressed in poor performance of growth as well as yield attributes. Nair and Peter (1990) confirmed that higher rates of NPK along with FYM increased the yield of chilli when compared to organic fertilizers alone or inorganic fertilizers alone. Akanbi et al., (2010) also confirmed that combined application of nitrogen with compost gave the highest fresh fruit yield in okra. Paramaguru and Natarajan (1993) reported that application of Azospirillum alone in chilli failed to show significant difference in dry fruit yield over no Azospillum. However, Azospirillum in combination with nitrogen increased the yield. Bahadur and Manohar (2001) also confirmed that plants inoculated with biofertilizer and not supplemented with inorganic fertilizer showed poor yield of okra.

\section{Quality}

Integration of higher levels of major nutrients with FYM/Vermicompost along with Azospirillum showed positive effect on the crude protein content of green fruit of okra (Table 3). 


\section{Int.J.Curr.Microbiol.App.Sci (2018) 7(10): 1686-1696}

Table.1 Influence of integrated nutrient management on leaf area index (LAI) and NAR at different growth stages of okra

\begin{tabular}{|c|c|c|c|c|c|c|c|c|c|c|c|c|}
\hline \multirow[t]{3}{*}{$\mathbf{T}$} & \multicolumn{8}{|c|}{ Leaf area Index (LAI) } & \multicolumn{4}{|c|}{ NAR (mg m ${ }^{-2}$ day $\left.^{-1}\right)$} \\
\hline & \multicolumn{4}{|c|}{2008} & \multicolumn{4}{|c|}{2009} & \multicolumn{2}{|c|}{2008} & \multicolumn{2}{|c|}{2009} \\
\hline & $\begin{array}{l}30 \\
\text { DAS }\end{array}$ & $\begin{array}{l}60 \\
\text { DAS }\end{array}$ & $\begin{array}{l}90 \\
\text { DAS }\end{array}$ & $\begin{array}{l}120 \\
\text { DAS }\end{array}$ & $\begin{array}{l}30 \\
\text { DAS }\end{array}$ & $\begin{array}{l}60 \\
\text { DAS }\end{array}$ & 90 DAS & 120 DAS & $60-30$ DAS & 90-60 DAS & $\begin{array}{l}60-30 \\
\text { DAS }\end{array}$ & $\begin{array}{l}90-60 \\
\text { DAS }\end{array}$ \\
\hline T1 & 0.15 & 1.37 & 1.47 & 1.03 & 0.18 & 1.78 & 1.80 & 1.31 & 17.72 & 27.45 & 18.16 & 24.60 \\
\hline $\mathrm{T} 2$ & 0.12 & 1.10 & 1.23 & 0.76 & 0.11 & 1.42 & 1.51 & 1.03 & 15.81 & 24.28 & 15.20 & 22.87 \\
\hline T3 & 0.08 & 0.94 & 1.08 & 0.68 & 0.10 & 1.14 & 1.37 & 0.87 & 11.76 & 23.07 & 14.47 & 21.00 \\
\hline T4 & 0.16 & 1.35 & 1.46 & 1.01 & 0.17 & 1.69 & 1.78 & 1.30 & 17.62 & 26.99 & 17.16 & 24.11 \\
\hline T5 & 0.10 & 0.92 & 1.14 & 0.67 & 0.10 & 1.17 & 1.47 & 0.89 & 14.63 & 24.09 & 16.56 & 21.29 \\
\hline T6 & 0.16 & 1.38 & 1.47 & 1.04 & 0.19 & 1.73 & 1.87 & 1.32 & 18.20 & 27.84 & 18.48 & 29.14 \\
\hline$\overline{\mathrm{T} 7}$ & 0.10 & 1.03 & 1.17 & 0.72 & 0.10 & 1.39 & 1.48 & 0.98 & 15.75 & 24.90 & 15.77 & 21.67 \\
\hline T8 & 0.15 & 1.38 & 1.48 & 1.03 & 0.16 & 1.75 & 1.81 & 1.29 & 17.87 & 27.45 & 17.20 & 24.32 \\
\hline T9 & 0.10 & 0.95 & 1.17 & 0.67 & 0.10 & 1.24 & 1.52 & 0.90 & 14.83 & 24.10 & 16.05 & 21.81 \\
\hline T10 & 0.16 & 1.39 & 1.50 & 1.04 & 0.17 & 1.79 & 1.90 & 1.31 & 18.72 & 28.32 & 21.52 & 31.82 \\
\hline T11 & 0.10 & 1.09 & 1.20 & 0.73 & 0.11 & 1.47 & 1.50 & 0.99 & 13.29 & 25.32 & 14.48 & 21.88 \\
\hline $\mathrm{T} 12$ & 0.09 & 0.71 & 0.94 & 0.61 & 0.09 & 0.97 & 1.28 & 0.81 & 9.01 & 22.20 & 12.85 & 20.83 \\
\hline T13 & 0.09 & 0.75 & 1.05 & 0.63 & 0.09 & 0.99 & 1.39 & 0.85 & 9.89 & 23.98 & 13.77 & 20.92 \\
\hline T14 & 0.09 & 0.71 & 0.94 & 0.59 & 0.09 & 0.98 & 1.26 & 0.79 & 8.87 & 22.09 & 12.15 & 17.59 \\
\hline T15 & 0.08 & 0.63 & 0.86 & 0.52 & 0.09 & 0.85 & 1.15 & 0.66 & 7.38 & 19.96 & 11.41 & 15.85 \\
\hline SEd \pm & 0.013 & 0.11 & 0.10 & 0.06 & 0.018 & 0.16 & 0.12 & 0.09 & 0.41 & 2.98 & 1.72 & 2.96 \\
\hline CD0.05 & 0.027 & 0.23 & 0.21 & 0.14 & 0.040 & 0.33 & 0.25 & 0.19 & 0.84 & NS & 3.52 & 6.06 \\
\hline
\end{tabular}


Table.2 Influence of integrated nutrient management on fresh and dry weight of plant $(\mathrm{g})$ at different growth stages of okra

\begin{tabular}{|c|c|c|c|c|c|c|c|c|c|c|c|c|c|c|c|c|}
\hline \multirow[t]{3}{*}{$\mathbf{T}$} & \multicolumn{8}{|c|}{ Fresh weight of plant (g) } & \multicolumn{8}{|c|}{ Dry weight of plant (g) } \\
\hline & \multicolumn{4}{|c|}{2008} & \multicolumn{4}{|c|}{2009} & \multicolumn{4}{|c|}{2008} & \multicolumn{4}{|c|}{2009} \\
\hline & $\begin{array}{l}30 \\
\text { DAS }\end{array}$ & $\begin{array}{l}60 \\
\text { DAS }\end{array}$ & $\begin{array}{l}90 \\
\text { DAS }\end{array}$ & $\begin{array}{l}120 \\
\text { DAS }\end{array}$ & $\begin{array}{l}30 \\
\text { DAS }\end{array}$ & $\begin{array}{l}60 \\
\text { DAS }\end{array}$ & $\begin{array}{l}90 \\
\text { DAS }\end{array}$ & $\begin{array}{l}120 \\
\text { DAS }\end{array}$ & $\begin{array}{l}30 \\
\text { DAS }\end{array}$ & $\begin{array}{l}60 \\
\text { DAS }\end{array}$ & $\begin{array}{l}90 \\
\text { DAS }\end{array}$ & $\begin{array}{l}120 \\
\text { DAS }\end{array}$ & $\begin{array}{l}30 \\
\text { DAS }\end{array}$ & $\begin{array}{l}60 \\
\text { DAS }\end{array}$ & $\begin{array}{l}90 \\
\text { DAS }\end{array}$ & $\begin{array}{l}120 \\
\text { DAS }\end{array}$ \\
\hline T1 & 1.95 & 30.34 & 151.70 & 141.83 & 2.03 & 32.46 & 161.33 & 155.22 & 0.28 & 5.56 & 26.88 & 24.97 & 0.30 & 5.86 & 28.60 & 26.39 \\
\hline $\mathbf{T 2}$ & 1.52 & 25.30 & 124.93 & 112.44 & 1.51 & 27.88 & 130.43 & 120.98 & 0.23 & 4.67 & 22.51 & 20.87 & 0.24 & 5.40 & 24.00 & 22.15 \\
\hline T3 & 1.25 & 19.12 & 89.86 & 87.20 & 1.28 & 20.27 & 95.27 & 90.70 & 0.21 & 3.36 & 16.67 & 15.50 & 0.20 & 3.30 & 17.83 & 16.53 \\
\hline T4 & 1.66 & 26.70 & 125.71 & 121.42 & 1.63 & 27.93 & 154.06 & 128.76 & 0.25 & 5.17 & 23.97 & 22.34 & 0.26 & 5.49 & 25.45 & 23.67 \\
\hline T5 & 1.23 & 23.56 & 115.21 & 112.45 & 1.25 & 24.86 & 120.82 & 118.04 & 0.22 & 3.83 & 21.06 & 19.42 & 0.21 & 4.50 & 22.50 & 20.97 \\
\hline T6 & 1.85 & 31.34 & 153.57 & 147.12 & 1.89 & 33.53 & 166.64 & 160.64 & 0.25 & 5.82 & 28.39 & 26.54 & 0.27 & 6.14 & 29.88 & 28.27 \\
\hline T7 & 1.33 & 24.72 & 117.67 & 113.01 & 1.37 & 26.20 & 126.71 & 124.81 & 0.22 & 5.04 & 22.26 & 21.72 & 0.23 & 5.27 & 24.82 & 23.18 \\
\hline $\mathrm{T} 8$ & 1.62 & 26.58 & 129.44 & 123.42 & 1.65 & 28.20 & 153.87 & 135.96 & 0.26 & 5.31 & 23.82 & 22.20 & 0.25 & 5.60 & 25.50 & 23.79 \\
\hline T9 & 1.22 & 24.23 & 118.73 & 113.60 & 1.29 & 25.64 & 124.87 & 119.30 & 0.23 & 4.55 & 18.16 & 16.75 & 0.22 & 4.76 & 19.42 & 18.02 \\
\hline T10 & 1.92 & 31.61 & 158.05 & 154.89 & 1.90 & 33.82 & 168.42 & 165.05 & 0.27 & 6.12 & 28.23 & 26.82 & 0.28 & 6.46 & 29.10 & 27.90 \\
\hline T11 & 1.34 & 25.27 & 128.20 & 118.07 & 1.40 & 27.82 & 136.32 & 130.48 & 0.21 & 4.32 & 20.77 & 19.23 & 0.21 & 4.51 & 22.10 & 20.42 \\
\hline T12 & 1.11 & 17.31 & 84.82 & 81.43 & 1.10 & 18.35 & 86.92 & 80.84 & 0.19 & 2.74 & 15.17 & 14.26 & 0.18 & 2.75 & 16.10 & 15.13 \\
\hline T13 & 1.13 & 17.91 & 88.12 & 82.83 & 1.15 & 18.98 & 90.43 & 84.10 & 0.19 & 2.99 & 16.00 & 15.15 & 0.17 & 3.12 & 16.95 & 15.93 \\
\hline T14 & 1.00 & 17.20 & 83.76 & 78.73 & 1.06 & 18.15 & 86.77 & 80.69 & 0.17 & 2.68 & 14.73 & 14.14 & 0.16 & 2.59 & 15.54 & 14.81 \\
\hline T15 & 0.87 & 16.79 & 79.75 & 75.76 & 0.90 & 17.81 & 84.59 & 77.65 & 0.15 & 2.20 & 14.35 & 13.80 & 0.16 & 2.30 & 15.10 & 14.42 \\
\hline SEd \pm & 0.29 & 2.50 & 13.21 & 11.42 & 0.25 & 2.85 & 10.50 & 15.41 & 0.03 & 0.51 & 2.15 & 2.39 & 0.03 & 0.50 & 2.13 & 2.46 \\
\hline CD 0.05 & 0.60 & 5.13 & 27.07 & 23.40 & 0.52 & 5.84 & 21.50 & 31.56 & 0.07 & 0.04 & 4.41 & 4.89 & 0.07 & 1.03 & 4.36 & 5.03 \\
\hline
\end{tabular}


Table.3 Influence of integrated nutrient management on nutrient content of leaf at flowering (\%), Green fruit yield ( $q / \mathrm{ha}$ ) and quality of okra

\begin{tabular}{|c|c|c|c|c|c|c|c|c|c|c|c|c|}
\hline \multirow[t]{3}{*}{$\mathbf{T}$} & \multicolumn{6}{|c|}{ Nutrient content of leaf at flowering (\%) } & \multicolumn{2}{|c|}{$\begin{array}{l}\text { Green fruit yield } \\
\text { (q/ha) }\end{array}$} & \multicolumn{2}{|c|}{$\begin{array}{l}\text { Crude protein content } \\
(\%)\end{array}$} & \multicolumn{2}{|c|}{$\begin{array}{l}\text { Crude fibre content } \\
(\%)\end{array}$} \\
\hline & \multicolumn{3}{|c|}{2008} & \multicolumn{3}{|c|}{2009} & \multirow[t]{2}{*}{2008} & \multirow[t]{2}{*}{2009} & \multirow[t]{2}{*}{2008} & \multirow[t]{2}{*}{2009} & \multirow[t]{2}{*}{2008} & \multirow[t]{2}{*}{2009} \\
\hline & $\mathrm{N}$ & $\mathrm{P}$ & $\mathrm{K}$ & $\mathrm{N}$ & $\mathrm{P}$ & $\mathrm{K}$ & & & & & & \\
\hline T1 & 2.71 & 0.49 & 2.24 & 2.85 & 0.49 & 2.28 & 156.47 & 159.07 & 15.30 & 11.70 & 15.80 & 10.82 \\
\hline T2 & 2.38 & 0.36 & 1.88 & 2.42 & 0.38 & 1.91 & 140.07 & 141.95 & 14.70 & 12.10 & 14.88 & 11.78 \\
\hline T3 & 2.25 & 0.32 & 1.74 & 2.37 & 0.34 & 1.78 & 120.24 & 123.87 & 13.30 & 12.25 & 13.25 & 11.88 \\
\hline $\mathrm{T4}$ & 2.48 & 0.47 & 2.19 & 2.63 & 0.47 & 2.26 & 157.20 & 153.21 & 17.10 & 10.10 & 16.75 & 9.65 \\
\hline T5 & 2.28 & 0.33 & 1.77 & 2.40 & 0.35 & 1.82 & 127.15 & 128.76 & 14.10 & 12.10 & 14.00 & 11.40 \\
\hline T6 & 2.79 & 0.49 & 2.18 & 2.94 & 0.48 & 2.24 & 159.26 & 160.35 & 17.59 & 10.00 & 17.68 & 9.49 \\
\hline T7 & 2.30 & 0.38 & 1.76 & 2.40 & 0.40 & 1.80 & 133.99 & 138.90 & 14.72 & 11.50 & 14.70 & 10.93 \\
\hline T8 & 2.46 & 0.50 & 2.21 & 2.60 & 0.50 & 2.27 & 157.01 & 158.43 & 17.50 & 9.90 & 16.95 & 9.30 \\
\hline T9 & 2.25 & 0.36 & 1.81 & 2.37 & 0.37 & 1.85 & 131.26 & 134.77 & 13.80 & 12.00 & 14.00 & 11.40 \\
\hline T10 & 2.85 & 0.51 & 2.21 & 3.00 & 0.53 & 2.25 & 162.12 & 162.68 & 17.70 & 9.70 & 17.83 & 9.40 \\
\hline T11 & 2.32 & 0.34 & 1.85 & 2.43 & 0.36 & 1.89 & 138.51 & 139.74 & 14.75 & 11.60 & 14.65 & 11.02 \\
\hline T12 & 2.23 & 0.32 & 1.69 & 2.32 & 0.32 & 1.72 & 100.00 & 101.98 & 13.10 & 10.70 & 13.00 & 10.57 \\
\hline T13 & 2.24 & 0.34 & 1.70 & 2.33 & 0.34 & 1.73 & 103.87 & 106.31 & 13.60 & 10.50 & 13.95 & 10.07 \\
\hline T14 & 2.21 & 0.32 & 1.69 & 2.32 & 0.30 & 1.72 & 96.77 & 99.01 & 12.80 & 11.80 & 12.65 & 11.88 \\
\hline T15 & 1.87 & 0.27 & 1.61 & 1.90 & 0.25 & 1.70 & 91.52 & 95.92 & 10.80 & 13.80 & 10.10 & 13.16 \\
\hline SEd \pm & 0.15 & 0.04 & 0.39 & 0.20 & 0.06 & 0.17 & 7.10 & 5.24 & 1.08 & 0.73 & 1.15 & 0.60 \\
\hline CD0.05 & 0.31 & 0.08 & NS & 0.41 & 0.12 & 0.35 & 14.56 & 10.74 & 2.22 & 1.50 & 2.35 & 1.22 \\
\hline
\end{tabular}


Table.4 Residual available NPK and nutrient balance (kg/ha) in soil after 2 years as affected by Integrated nutrient management in okra

\begin{tabular}{|c|c|c|c|c|c|c|c|c|c|c|c|c|c|c|c|}
\hline \multirow[t]{2}{*}{$\mathbf{T}$} & \multicolumn{5}{|c|}{ N (kg/ha) } & \multicolumn{5}{|c|}{$\mathrm{P}_{2} \mathrm{O}_{5}$ (kg/ha) } & \multicolumn{5}{|c|}{$\mathrm{K}_{2} \mathrm{O}(\mathrm{kg} / \mathrm{ha})$} \\
\hline & $\begin{array}{l}\text { Initial } \\
\text { status }\end{array}$ & $\begin{array}{l}\text { Nutrient } \\
\text { added by } \\
\text { treatment }\end{array}$ & $\begin{array}{l}\text { Nutrient } \\
\text { removed } \\
\text { by crop }\end{array}$ & $\begin{array}{c}\text { Final } \\
\text { balance }\end{array}$ & $\begin{array}{l}\text { Net } \\
\text { gain/ } \\
\text { loss }\end{array}$ & $\begin{array}{l}\text { Initial } \\
\text { status }\end{array}$ & $\begin{array}{l}\text { Nutrient } \\
\text { added by } \\
\text { treatment }\end{array}$ & $\begin{array}{l}\text { Nutrient } \\
\text { removed } \\
\text { by crop }\end{array}$ & $\begin{array}{c}\text { Final } \\
\text { balanc } \\
\text { e }\end{array}$ & $\begin{array}{l}\text { Net } \\
\text { gain/ } \\
\text { loss }\end{array}$ & $\begin{array}{l}\text { Initial } \\
\text { status }\end{array}$ & $\begin{array}{l}\text { Nutrient } \\
\text { added by } \\
\text { treatment }\end{array}$ & $\begin{array}{l}\text { Nutrient } \\
\text { removed } \\
\text { by crop }\end{array}$ & $\begin{array}{c}\text { Final } \\
\text { balance }\end{array}$ & $\begin{array}{l}\text { Net } \\
\text { gain/ } \\
\text { loss }\end{array}$ \\
\hline $\mathbf{T}_{1}$ & 320 & 80.00 & 97.32 & 304.60 & +1.92 & 25.08 & 60 & 22.62 & 24.20 & -38.26 & 450 & 30.00 & 78.76 & 483.00 & +81.76 \\
\hline $\mathbf{T}_{2}$ & 320 & 60.00 & 87.00 & 287.30 & -5.70 & 25.08 & 45 & 20.18 & 22.20 & -27.70 & 450 & 22.50 & 70.39 & 478.75 & +76.64 \\
\hline $\mathbf{T}_{\mathbf{3}}$ & 320 & 40.00 & 75.32 & 271.15 & -13.53 & 25.08 & 30 & 17.50 & 20.30 & -17.28 & 450 & 15.00 & 60.93 & 450.50 & +46.43 \\
\hline $\mathbf{T}_{4}$ & 320 & 82.00 & 95.76 & 304.50 & -1.74 & 25.08 & 52 & 22.25 & 22.40 & -32.43 & 450 & 45.00 & 77.48 & 478.75 & +61.23 \\
\hline $\mathbf{T}_{5}$ & 320 & 65.50 & 78.96 & 296.00 & -10.54 & 25.08 & 37 & 18.34 & 20.50 & -3.24 & 450 & 30.00 & 63.87 & 459.00 & +42.87 \\
\hline$T_{6}$ & 320 & 82.00 & 98.60 & 305.60 & +2.20 & 25.08 & 52 & 22.90 & 23.20 & -30.98 & 450 & 45.00 & 79.77 & 493.00 & +77.77 \\
\hline $\mathbf{T}_{7}$ & 320 & 62.50 & 84.20 & 286.25 & -12.05 & 25.08 & 37 & 19.56 & 20.60 & -18.92 & 450 & 45.00 & 68.11 & 454.75 & +27.86 \\
\hline $\mathbf{T}_{8}$ & 320 & 108.00 & 97.32 & 338.10 & +7.42 & 25.08 & 66 & 22.61 & 27.60 & -37.87 & 450 & 47.50 & 78.73 & 510.00 & +91.23 \\
\hline$T_{9}$ & 320 & 88.00 & 89.08 & 306.70 & -12.22 & 25.08 & 51 & 19.07 & 21.26 & -35.75 & 450 & 40.00 & 66.40 & 459.00 & +35.40 \\
\hline $\mathbf{T}_{10}$ & 320 & 108.00 & 100.16 & 335.75 & +7.91 & 25.08 & 66 & 23.28 & 28.28 & -39.52 & 450 & 47.50 & 81.07 & 501.50 & +85.07 \\
\hline $\mathrm{T}_{11}$ & 320 & 88.00 & 85.84 & 308.60 & -13.56 & 25.08 & 51 & 19.95 & 21.00 & -35.13 & 450 & 40.00 & 69.45 & 467.50 & +46.95 \\
\hline $\mathbf{T}_{12}$ & 320 & 22.50 & 62.32 & 268.50 & -11.68 & 25.08 & 7 & 14.48 & 17.00 & -0.60 & 450 & 15.00 & 50.41 & 442.00 & +27.41 \\
\hline $\mathbf{T}_{13}$ & 320 & 48.00 & 64.84 & 292.75 & -10.41 & 25.08 & 21 & 15.06 & 20.40 & -10.62 & 450 & 25.00 & 52.46 & 437.75 & +15.21 \\
\hline$T_{14}$ & 320 & Nil & 60.40 & 249.25 & -10.35 & 25.08 & Nil & 10.03 & 14.00 & -1.05 & 450 & Nil & 48.87 & 420.50 & +19.37 \\
\hline$T_{15}$ & 320 & Nil & 57.84 & 247.55 & -14.61 & 25.08 & Nil & 9.44 & 14.00 & -1.64 & 450 & Nil & 46.79 & 417.75 & +14.54 \\
\hline
\end{tabular}


This is in agreement with the findings of Abusaleha and Shanmugavelu (1988) and Olaniyi et al., (2010) in okra. Raj and Kumari (2001) also reported increased in crude protein content of okra fruit with the application of manure and Azospirillum.

Combination of major nutrients + organic manures and biofertilizer decreases the crude fibre content of green fruit in okra and it was confirmed by the earlier report of Olaniyi et al., (2010) and Wagh et al.,(2014). Abusaleha and Shanmugavelu (1988) also found that application of organic form of nitrogen combined with inorganic form lowered the crude fibre content of fruit in okra and highest crude fibre content in control as in the present study. Similar reduction in crude fibre content of okra was obtained by the application of FYM + enriched compost (Raj and Kumari, 2001).

\section{Residual NPK status of soil (kg/ha) and nutrient balance}

Combined application of $75 \%$ recommended dose of NPK + Vermicompost along with Azospirillum recorded higher residual available NPK in soil after the harvest of the crop (Table 4). The increase in available NPK indicated that nitrogen, phosphorus and potassium present in the Vermicompost was available to the crop and the application of FYM, inorganic fertilizers and Vermicompost would have increased the available NPK content in soil. Similar results were obtained in okra by Barani and Anburani (2004), Phonglosa et al., (2015) and Kumar et al., (2017).

Integration of organic and inorganic source of nutrients or applying the recommended dose of inorganic fertilizers resulted in positive nitrogen balance. Such positive balance nitrogen with the application of $75 \%$ recommended dose of fertilizer with
Vermicompost at $2.7 \mathrm{t} / \mathrm{ha}$ was also reported by Nanjappa et al., (2001). The negative balance of nitrogen as observed with lower dose of NPK combined with organic manure or Azospirillum or independently is also supported by Tanwar et al., (2010). There was negative balance of $\mathrm{P}_{2} \mathrm{O}_{5}$ in all the treatment, however, the degree was less when organics were combined with inorganics at lower dose. The negative balance may be attributed to fixation of available $\mathrm{P}_{2} \mathrm{O}_{5}$ as reported by Nanjappa et al., (2001). Though positive balance was observed for $\mathrm{K}_{2} \mathrm{O}$ in all the treatments, however, the gain was higher when $75 \%$ recommended dose of fertilizer was applied with Vermicompost. The gain in $\mathrm{K}_{2} \mathrm{O}$ might be due to decrease in shifting equilibrium of $\mathrm{K}_{2} \mathrm{O}$ in the soil and also reduced leaching losses. Nanjappa et al., (2001) also confirmed that combined application of organic and inorganic chemical fertilizers in maize resulted gain of $\mathrm{K}_{2} \mathrm{O}$.

\section{References}

Abusaleha and K.G. Shanmugavelu. 1988. Studies on the effect of organic vs inorganic source of nitrogen on growth, yield and quality of okra (Abelmoschus esculentus). Indian J. Hort., 45 (3\&4): 312-318.

Akanbi, W.B., A.O. Togun, J.A. Adediran and E.A.O. Ilupeju. 2010. Growth, dry matter and fruit yields components of okra under organic and inorganic sources of nutrients. American-Eurasian J. Sustainable Agric., 4 (1): 1-13.

Akande, M.O., F.I. Oluwatoyinbo, E.A. Makinde, A.S. Adepoju and I.S. Adepoju. 2010. Response of okra to organic and inorganic fertilization. Nature and Sci., 8 (11): 261-266.

BahadurAnant and R.K. Manohar. 2001. Response of okra to biofertilizers. Veg. Sci., 28 (2): 197-198. 
Barani, P. and A. Anburani. 2004. Influence of vermicomposting on major nutrients in bhendi (Abelmoschus esculentus L. Moench) var. ArkaAnamika. South Indian Hort., 52 (1-6):170-174.

Chauhan, D.V.S. 1972. Vegetable production in India ( $3^{\text {rd }}$ Edition). Ram Prasad and Sons, Agra.

Chopra, S.L. and J.S. Kanwar. 1976. Analytical Agricultural Chemistry. Kalyani Publishers, New Delhi. pp. 296.

El-Kader, Abd, A.A., S.M. Shaaban and M.S. Abd El-Fattah. 2010. Effect of irrigation levels and organic compost on okra plants (Abelmoschus esculentus L.) grown in sandy calcareous soil. Agric. Biol. J. N. Am., 1 (3): 225-231.

Enyi, B.A.C. 1962. Comparative growth rates of upland and swamp rice varieties. Ann. Bot., (26): 467-487.

Gaur, AC., S. Neelakantan and K.S. Dargan. 1984. Organic manures, ICAR, New Delhi. 159.

Jackson, M.L. 1973. Soil Chemical Analysis. Prentice Hall of India (Pvt.) Ltd., New Delhi.

Kumar, V., Saikia, J. and Nath, D.J. (2017). Effect of integrated nutrient management on growth, yield, and quality of okra (Abelmoschus esculentus (L). Moench) cv. Arka Anamika. International J. of Chemical Studies. 5(5): 2001-2003.

Mishra, R.K., Ganesh Singh and S.N.S. Chaurasia. 2005. Effect of sources of nutrients on performance of okra. Sri Lankan J. Agric. Sci., (42): 52-57.

Muresan, R. and H. Popescu. 1993. Abelmoschus esculentus L. Moench. Cultivatla Cluj ca sursa de poliholozide. Clujul Medical, 66: 267-274.

Naidu, A.K., S.S. Kuswah and Y.C. Dwivedi. 2002. Influence of organic manures, chemical and biofertilizers on growth, yield and economics of brinjal. South Indian Hort., 50 (4-6): 370-376.
Nair Meena and K.V. Peter. 1990. Organic, inorganic fertilizers and their combinations on yield and storage life of hot chilli. Veg. Sci., 17 (1): 7-10.

Nanjappa, H.V., B.K. Ramachandrappa and B.O. Mallikaryana. 2001. Effect of integrated nutrient management on yield and nutrient balance in maize. Indian $\mathrm{J}$. Agron., 46 (4): 698-701.

Olaniyi, J.O., W.B. Akanbi, O.A. Olaniran and O.T. Ilupeju. 2010. The effect of organo-mineral and inorganic fertilizers on the growth, fruit yield, quality and chemical composition of okra. J. Animal and Plant Sci., 9 (1): 11351140.

Paramaguru, P. and S. Natarajan. 1993. Effect of Azospirillum on growth and yield of chilli (Capsicum annum L.) grown under semi-dry condition. South Indian Hort., 41(2): 80-83.

Phonglosa, A., Bhattacharyya, K., Ray, K., Mandal, J., Pari, A., Banerjee, H., and Chattopadhyay, A. 2015. Integrated nutrient management for okra in an inceptisol of eastern India and yield modeling through artificial neural network. Scientia Horticulturae 187: 1-9

Raj, A.K. and V.L.G Kumari. 2001. Effect of organic manures and Azospirillum inoculation on yield and quality of okra (Abelmoschus esculentus L. Moench). Veg. Sci., 28 (2): 179-181.

Sachan, S., Singh, D., Kasera, S., Mishra, S.K., Tripathi, Y., Mishra, V. and Singh, R.K. 2017. Integrated nutrient management (INM) in Okra (Abelmoschus esculentus (L.) Moench) for better growth and higher yield. J. of Pharmacognosy and Phytochemistry. 6 (5): 1854-1856

Schipper, R.R. 2000. African indigenous vegetables. Netherlands, pp. 103-118.

Shukla, V. and L.B. Naik. 1993. AgroTechnique for Malvaceae vegetables, In: Advances in horticulture vol. 5. 
Malhotra publishing house, New Delhi, India, pp. 399-425.

Singh, S.S., 1996. Soil fertility and nutrient management. Kalyani Publishers, New Delhi.

Singh, T.R., S. Singh, S.K. Singh, M.P. Singh and B.K. Srivastava. 2004. Effect of integrated nutrient management on crop nutrient uptake and yield under okrapea-tomato cropping system in molisol. Indian J. of Hort., 61 (4): 312-314.

Tanwar, S.P.S., P. Rokadia and A.K. Singh. 2010. Productivity, nutrient balance and economics of kabuli chickpea as influence by integrated nutrient management. Indian J. Agron., 55 (1): 51-55.
Thompson, H.C. 1949. Vegetable crops, Mc Graw Hill Book Company, Inc. New York, Toronto, London, 611pp.

Tindall, H.D. 1983. Vegetables in the Tropics. Macmillan Education Ltd. Houndmills Hamsphire, pp: 533.

Wagh, S.S., Laharia, G.S., Iratkar, A.G., and Gajare, A.S., 2014. Effect of INM on nutrient uptake, yield and quality of okra [Abelmoschus esculents (L.) Moench]. An Asian J. of Soil Sci. 9 (1): 21-24.

Yadav, R.L. 1981. Nitrogen and phosphorus balance of soil as affected by sugarcane intensive crop rotation. Indian J. Agron., 26 (3): 267-271.

\section{How to cite this article:}

Mariam Anal Ps., Edwin Luikham, Ps. Munsi and Meitei, W.I. 2018. Growth, Productivity and Quality of Okra (Abelmoschus esculentus L.) cv. Prabhani Kranti and Nutrient Balance in Soil under Chemical Fertilizers, Organic Manures and Biofertilizers in Sub-Tropical Condition. Int.J.Curr.Microbiol.App.Sci. 7(10): 1686-1696. doi: https://doi.org/10.20546/ijcmas.2018.710.193 